\title{
Seeking for a Sense of Belonging: An Interpretation of Song of Solomon
}

\author{
Jin-lian $\mathrm{Wu}$ \\ Teacher of School of foreign languages, Inner Mongolia University for Nationalities \\ Tongliao, Inner Mongolia, China \\ E-mail:wj13623@126.com
}

Received: April 3, 2012

Accepted: April 24, 2012

Published: June 1, 2012

doi:10.5539/ells.v2n2p39

URL: http://dx.doi.org/10.5539/ells.v2n2p39

The research of this thesis is sponsored by Inner Mongolia University for Nationalities (serial number: MDX2010043).

\begin{abstract}
Toni Morrison's works usually show deep concern not only for the existence and development of the black but also that of human beings. By presenting the story of Dead family in Song of Solomon, Morrison tries to find a way out for black people as well as the whole mankind in this pluralistic modern world. The black's loss in the novel represents modern men's loss in a world full of material desires. The protagonist Milkman's unwitting search for his root enlightens the puzzled modern human beings. The thesis attempts to interpret Morrison's view of sense of belonging by analyzing the loss of three Macons, the experience of Pilate and the return journey of Milkman. On the whole, it aims at exploring Morison's proposition that it is essential for one to return to pure traditional culture, nature and one's true self, thereby owning a sense of belonging.
\end{abstract}

Keywords: African American, Search, Ancestral culture, Nature, Self identity

\section{Introduction}

Toni Morrison acted as a helmsman of the third high tide of African-American literature in the $20^{\text {th }}$ century. She is a prominent African American female writer. "Indeed, certain critics would seek to compliment Morrison by describing her as something more than an African American, or woman, or black woman writer" (Smith, 2007, p. 2). She pays much attention not only to African Americans' existence but also to that of human beings' in a world full of material desires. To a certain degree, black people in her works are representatives of mankind since African Americans are human beings first, and then the black. Morrison reflects deeply on the existence of human beings by creating stories of black people. In Morrison's opinion, finding a sense of belonging is essential for the existence and development of human beings who tend to live aimlessly and consider life boring and meaningless. One cannot live meaningfully without owning a sense of belonging. A sense of belonging is one of the ancient necessities of human beings. If one wants to own a sense of belonging, he or she needs to comprehend one's true self, return to their pure traditional culture and the simple natural life, in other words, return to the basics. Morrison expounds her view on this in most of her works, especially in her third novel, Song of Solomon. The novel has "changed Toni Morrison's public reputation from aspiring novelist to outstanding American writer" (McKay, 1988, p. 4). Morrison highlights the necessity of owning a sense of belonging through the portrayal of Dead family, in particular, the protagonist Milkman in the novel. The fate of African Americans in the novel can give enlightenment to contemporary people in the United States of America as well as the other parts of the world.

\section{The Blacks' Sense of Loss}

With the high-speed development of the economic society, modern people often have a sense of loss due to lack of spiritual substance. The obvious contrast between rich material life and poor spiritual life makes modern people feel confused, empty and lonely. Modern people tend to forget tradition, ancestral culture and true self, thereby losing themselves during their blind material pursuit, especially those who live in a heterogeneous cultural background, such as African Americans in Morrison's Song of Solomon. These black people who are mired in self-identity crisis feel a strong sense of loss and rootless. They are often uncertain about the answer to the question "Who am l?"

\subsection{The First Macon's Loss}

The members of Dead family in Song of Solomon are physically alive while spiritually dead as their surname 
"Dead" indicates. They are "dead" for they are cut off from knowledge of their ancestral name and ancestral past. Because of certain white registrar's ignorance and carelessness, the Dead family is deprived of its real name derived from the paternal ancestor. Macon Dead I, originally named as Jake Solomon, goes to register his name at the end of the Civil War. The drunken white registrar inquires him of the place of birth as well as his father's name. He tells the registrar that his place of birth is Macon and that his father is dead. The negligent registrar puts down Macon (the place of birth) as the first name and Dead (the fate of the patriarch's father) as the last. Thus, illiterate Jake Solomon is misnamed as Macon Dead and hands down the humiliating name from one generation to another. Because his wife Sing thinks that the new name can wipe out the past, the first Macon keeps it willingly, unconscious of losing his true self. He expects that his new name can give him a new fate. He works hard to build his kingdom "Lincoln's Heaven" and never expects that he will be killed by the white who intend to occupy his farm.

Morrison uses "naming as the epitome of the continuing and haunting presence of the past" (Rigney, 1991, p. 41). She once states, "If you come from Africa your name is gone. It is particularly problematic. Because it is not just your name but your family, your tribe. When you die, how can you connect with your ancestors if you have lost your name? That's a huge psychological scar." (Morrison, 1994, p. 126). That is the reason why Macon Dead I cannot get rid of the deep sense of loss even after his death and his soul returns to his daughter Pilate again and again. He wants Pilate to help him find the lost names so that he can connect with his ancestors. He repeats the word "Sing" to Pilate whenever he comes back to her. So Pilate sings all the time, but she cannot comprehend the real meaning of his father. In fact, on one hand, Macon Dead I repeats his wife's name which has been lost since her death; on the other hand, he might expect Pilate to find the clue to their real family name by singing the blues which contains the African American tradition and the origin of African American culture. One's family name is badge of one's identity. By repeating the word "Sing", Macon Dead I actually asks her daughter to recover the lost names of his family. The lost names which represent Deads' real identity are an essential part of the legacy which must be cared for. Macon Dead I knows that his offspring cannot figure out who they are and where they are rooted without recovering their real family name. That is to say, they cannot get rid of the pain of feeling a sense of loss and feel a sense of wholeness without regaining their ancestors' names.

\subsection{The Second Macon's Loss}

Macon Dead II is a typical example of lost black souls under the influence of white dominating culture. In order to avoid his father's tragedy, he moves away from the south to the north and does his utmost to possess property and money in the urban area. He tries every possible means to seek for urban respectability and success. And he tries to fit into the main currents of culture by obtaining and enjoying great material wealth. However, he loses himself gradually in the process of merging into the white-dominating society. He is far away from the simple human nature during his obsessive search for material success. He becomes a puzzled, isolated and sad whitened black man.

Macon Dead II tries to own himself and control his fate by the means of obtaining material wealth in the north. However, he fails to own himself and become enslaved to the material things he acquires ironically. His single-minded ambition, his unscrupulous greed, his unabashed materialism, his betray of the ancestors' traditional culture and his abandonment of nature has changed him, unrecognizably from a "nice boy" to a stern, greedy, selfish, parsimonious and unloving man. The only thing the acquisitive black property owner and land developer cares about is to possess the material wealth. There is no love in his world. He marries Ruth for personal advancement rather than love, and he disowns his only sister Pilate just for a bag of gold. He is a distant husband, father and brother, contemptuous of his wife, children and sister. He forgets his black identity gradually and looks down upon the poor black. When Porter, a tenant of his, threatens to commit suicide, he hurries to go to the scene to collect his rents but not to save life. He even calls Porter - his fellowman "nigger". The second Macon's inhumanity to the people around him results from his being away from the black culture and nature. In Pilate's memory, when they lived in their farm and were in the embrace of the black culture and nature, he was a very nice person. He used to take good care of the motherless Pilate and help his father work in the farm. He loved his family members deeply then. At that time, he was a nice brother and a nice son. However, his inflated desire for material wealth drives him away from all of these. He is not the simple, honest and kind boy any longer.

He does obtain the material success he longs for, but he does not feel happy. Although he lives in a big comfortable house and often drives his family members in his luxurious car to show off his wealth, he senses a kind of indescribable emptiness and loneliness because he is spiritually impoverished and physically alienated from self, family, community and nature. When he wanders in the dark one evening to his sister Pilate's house and listens to her singing of eloquent blues in a powerful contralto outside her window unnoticed, he senses a kind of special peace in his mind. The pity of it is that he is not aware of the necessity of returning to the black culture, nature and his true self even in that moment. "Brief reflections such as these show us the cultural tensions and distance between Macon's boyhood rituals and freedom - the emotional wealth of his youth - and the materialistic values to which he 
adheres as a man"(Middleton, 2007, p. 28). "Macon Dead represents that historic moment when blacks broke with their agrarian background, identified with bourgeois values, yet lacked a language in which to define themselves" (Hubbard 1994, p. 130). Therefore, he can never get rid of his sense of loss because he ignores and suppresses the inner, cultural voices of survival from his past.

\subsection{The Third Macon-Milkman's Loss}

Being completely estranged from the African traditional culture and black community and greatly influenced by his father, Milkman becomes an irresponsible, frivolous and indifferent man and regards the acquisition of property as the most important thing. "Milkman appears to be destined for a life of self-alienation and isolation because of his commitment to the materialism......" (Smith, 2007, p. 11). He feels lonely, bewildered and aimless. He even limps physically due to his psychological unsoundness. He inherits not only his father's materialistic value orientation but also his father's greed, selfishness and callosity. He never cares about others' feelings. He knows that his mother loves him deeply, but he is not considerate of her helplessness and loneliness at all; he knows Hagar is infatuated with him, but he abandons her like a wad of chewing gum after he has fed up with her; he knows Pilate once helps his mother to save his life, but he betrays her just for a bag of gold. Because of the lack of the consciousness of the ancestral culture and nature, he loses himself during the process of pursuing property blindly just like his father.

What need particularly noteworthy in the novel are Milkman's dream of flying in his childhood and the recurring image of the white peacock. The white peacock implies Milkman's material value and the white cultural values he worships blindly. He wonders about the white peacock's inability to fly. Guitar explains the reason to him, "too much tail. All that jewelry weighs it down. Like vanity. Can't nobody fly with all that shit. Wanna fly, you got to give up the shit that weighs you down" (pp. 179-80). To a certain degree, Guitar's words give enlightenment to Milkman. The words teach him how to fly. However, flying is an important part of African culture. Milkman cannot comprehend the true essence of flying without retuning to his ancestral culture.

\section{The Blacks' Search for a Sense of Belonging}

It is natural and necessary for human beings to seek a sense of belonging. In order to relieve the pain of getting lost, one has to trace back to one's root and come close to nature for a sense of belonging. The lost African Americans' eudemonia can derive from their returning to their ancestral culture, their returning to nature and their recognizing of their selves, in other words, their owning of a sense of belonging.

\subsection{Return to the Pure Traditional Culture}

From a certain degree, to seek a sense of belonging means to identify with the ancestors' traditional culture. Morrison explains this point of view of hers through Pilate's journey around the whole country and Milkman's journey back to his ancestral past-a journey home in Song of Solomon.

\subsubsection{Pilate's Journey Back to the Ancestral Culture}

After the death of her father and separation from her brother, Pilate sets on a journey to Virginia, the hometown of her parents, driven by a desire for a place of belonging. She wanders from one place to another and works with different groups of blacks before she reaches Virginia where she feels a kind of unforgettable comfort among the blacks and gives birth to her daughter. Soon after the birth of her daughter, at the request of her father's soul, she returns to the cave in Denville to collect the bones which she thinks belongs to the white man and put them into a bag. Then she carries the bag on her back wherever she goes. Even when she travels around the whole country with her daughter because of the urge from her inner world, she takes the bag with her. She always thinks she carries with her the bones of the white man murdered by her brother. Pilate's deeds demonstrate the Christian thought penetrating Morrison's works, namely, universal fraternity and benevolence, which are also traditional African virtues. Morrison thinks that one should recognize and love one's ancestral culture; meanwhile, one need respect and tolerate others' culture.

Therefore, Pilate's deeds deserve the reward she receives later. The bones she has been carrying with her turn out to be the remains of her father. The owner of the remains is even named as Solomon by her unconsciously. It is really a reward for her glorious humanity. In a certain sense, the bag of bones connects her with her ancestral culture and she finds a sense of belonging by carrying it. And she travels around the whole country to follow her ancestors' footprints for a greater sense of belonging. On the way to Virginia, she becomes interested in geography and receives a geography book from a geography teacher. From then on, everywhere she goes she always keeps the geography book with her and picks up a piece of rock as souvenir. She reviews her ancestors' history by carrying and reading the geography book. And the rocks which she collects represent not only her own memory but also her ancestors' memory since the rocks Pilate collects may be the ones on which her ancestors once walked on. In order to get liberation and freedom, the blacks have migrated from one place to another and left their traces in every part 
of America in history. Being familiar with and nurtured by her ancestral culture through her journey, Pilate no longer feels perplexed and lonely and is able to reject the white values that entraps Macon Dead II and Milkman. She is optimistic, generous, accommodating and independent. "All these traits connect her to her African past, and give her the sustenance required for surviving whole in a world given to the emptiness of etiquette and the artificiality of modern survival techniques"(Ahmad, 2008, p. 67).

\subsubsection{Pilate's Influence upon Milkman}

Under the guidance of his aunt, his spiritual mother, Pilate, Milkman's consciousness of questing for his root awakens. "Thanks to Pilate, the uncomfortable boy foresees a future, is given a sense of hope" (Fabre, 1988, p. 110). Pilate is deeply rooted in black tradition and is a natural embodiment of black tradition and incarnation of ancient wisdom. Her house is a fecund place, the seedbed of cultural activity of the black where memory and music interact to give meaning to life. Her song about Sugerman embodies African American traditional culture. "Song is the Negro's mother. She nurtures him, soothes him, pacifies him, glorifies him. She keeps his heart cheered when the weight of an oppressive world would bend his body to the sod" (Fauset, 1996, p. 229). Therefore, Milkman is so absorbed in her wonderful song. He is completely fascinated by her high mood, her optimistic mind, and her spiritual height when he stays with her, and he feels a kind of cozy, comfortable and harmonious atmosphere of family at her home. He feels happy heartedly for the first time in his life at her home. He learns about his grandfather's death and Lincoln's Heaven, the beautiful farm, where his father and aunt spent their childhood. Later, his father adds more to the story of their hometown. For the first time Milkman comes close to his family history and ancestral culture. The information of his family history and the meeting of Pilate make him feel relieved, self-confident, and ready to embrace new things he may encounter. Milkman's first visit to Pilate's home initiates his journey to the African traditional culture and the simple nature.

Then he is on the journey from the north to the south in search of gold. At first, he just wants to quest for the missing gold so that he can become independent from his family. Later, as he progresses into his journey and goes deeper to the south, the heart of the black culture, his quest for gold becomes a quest for his ancestral culture, namely, a sense of belonging unwittingly. During his journey, "he slowly tries to piece together the history of his ancestors, which he achieves by journeying into his father and aunt's past, searching for his origins" (Zhao, 2011, p. 592).

\subsubsection{Denville - The First Station of Milkman's Ancestral Culture}

Milkman arrives at Denville, Pennsylvania, his father's hometown first to search for the cave where the gold might be hidden. Pilate and his father have ever told him the story of their hometown, Lincoln's Heaven and his grandfather's death. There, he hears the story again several times from Reverend Cooper and other aged people who know his grandfather and father well. From them, he learns much more information about his ancestry and gets a sense that he is included in the larger Dead family. "As the past becomes vivid in the words of the old men, Milkman sees the pattern of his father's life emerge, and he understands that the past he hears about shaped the present he knows" (Lobodziec, 2010, p. 115). The story which has been so exotic once sounds true and familiar now. He listens to the story attentively and feels proud of his family glory. He senses kindness and sincerity of the local black people and is aware of his blackness and the concept of community for the first time. And he begins to realize that there is something more important than money through his association with the local blacks.

The subsequent journey to the cave under the direction of Circe brings him closer to his ancestral culture. From Circe he learns about his grandparents' real names and their birthplace Shalimar. The cave where his father believes Pilate hid the gold and where his grandfather's remains lay is symbolized as his cultural womb. He passes the wood, crosses a creek and climbs a rocky hill to reach the cave. When he crosses the creek, he slips into it and is drenched to the skin, which symbolizes a kind of ritual cleaning and preparation for his rebirth. And his watch and cigarettes, the symbols of distraction and city life, are smashed and soaked on the way to the cave, which indicates his materialistic values fade and he is closer to the African traditional culture. Being closer to his community and his traditional culture through the journey to Danville, his inner national consciousness arises in both conscious and subconscious ways.

Failing to obtain the gold in Danville, he goes to Shalimar in Virginia to trace Pilate's journey so as to find the gold. In fact, as he moves forward to Shalimar, he continues his quest for the sense of belonging.

\subsubsection{Shalimar - The Terminal Station of Milkman's Ancestral Culture}

Shalimar is portrayed as a traditional African community, where black people lead a primitive and tranquil life. Milkman arrives at a more complete understanding of the meaning of community and traditional African culture there. In the beginning, Milkman seems to be an outsider. His participation in the bobcat hunt is a turning point. He is accepted by the black community after the hunt. 
The night hunting tests Milkman's courage and endurance and makes him understands the local blacks and his ancestral culture. In order to go hunting, Milkman takes off his fine clothes and puts on a suit of old uniform, which symbolizes he begins to acquire a new cultural identity. Due to his own ignorance of hunting, he has to depend on the local blacks during the hunting and has the chance to witness the local people's determination and courage. He begins to respects them and comprehends his ancestral culture. Hunting culture is a crucial and indispensable part of African culture. Through the hunting, he understands the blacks' primary link to nature.

His experience of joining with the local blacks in the slicing of the hunted bobcat helps him comprehend his ancestral culture better. During the process of the slicing, the local blacks ask him to get the heart out of the bobcat. "Don't get the lungs, now. Get the heart" (p. 282).This sentence symbolizes Milkman's heartlessness before the trip to the south. He does not attempts to reflect deeply on what he really wants and what other people want until the moment he integrates himself into the local black community. Then he realizes that the purpose of his journey is not to find the lost gold but his lost humanity. "Humanism is a traditional African principal valued more than money and held in esteem more by the African masses than the African petty bourgeois"(Mbalia, 1991, p. 60). In his ancestors' world, the African traditional cultural values prevail over individualism and materialism. In the meantime, he watches a peacock soar away. With the abandoning of his material value and purification of his mind, the handicapped "peacock" finally can fly high. Then the experience at Sweet's home makes him learn to think in other's shoes. Sweet, a lovely woman in Shalimar receives him affectionately after his hunting experience. His unselfish and authentic love for Sweet is a striking contrast to his callousness to other women in his life before, especially his cousin Hagar. "The language with its harmony describing their actions following lovemaking, shows the responsibility Milkman now gladly undertakes. The repeated juxtaposition of "he" and "she" draws the wider circle of readers into the universal sweetness that comes from shared caring and giving" (O'Shaughnessy, 1988, p. 130). In the home of Sweet, Milkman finds the meaning of life, discovers giving and sharing, understands the essence of love and responsibility and feels no longer lonely, empty and bewildered. He is reborn. The bath he takes before lovemaking there symbolizes his rebirth and cultural immersion in the ancestors' pure traditional culture.

And the subsequent understanding of his great grandfather Solomon's flight which enhances his understanding of his ancestral culture helps him fulfill his dream of flying in his childhood. While sleeping in Sweet's bed, Milkman has "a warm dreamy sleep all about flying" (p. 302). He begins to be a real African.

\subsection{Return to the Simple Nature}

In addition to returning to the ancestors' pure traditional culture, Morrison believes, returning to nature is also of great importance for modern civilized people to own a sense of belonging.

\subsubsection{Pilate - An Embodiment of Nature}

Man and nature are interdependent. If human beings are far away from nature with the advance in civilization, science and technology, the basic humanity of human beings will get lost during the process of pursuing material wealth. A typical example of this is Macon Dead II. The harmonious development of humanity lies in the harmonious unity between man and nature. So only respecting nature fully, utilizing and exploiting nature scientifically can be of benefits to human beings. To be close to nature and reconnect with the simple things in life is as critical as food and water to the human beings.

Pilate Dead, the woman who looks like a tall black tree is a representative of those who live a natural life. Because she is not invaded by civilization, she is natural, optimistic, generous, resourceful and independent. She scorns civilized creature comforts and shows a sheer disregard for status, occupation, hygiene and manners. Although she lives in a small narrow house without electricity, gas, running water or any modern equipment and leads a very ancient life, she feels happy and fulfilled. She ekes out a satisfying life for herself and lives in harmony with nature. Behind her house are tall and big pine trees. She uses the pine needles as her cushion and often chews the pine needles in her mouth. Therefore, there is an odor of the forest in her mouth. Moreover, her house smells of pine and fermenting fruits. She takes simple natural things such as boiled eggs, fruits, corn and milk as her food and she looks strong and healthy. These kind of natural and ancient living conditions give her unique personal charm. She occupies little material wealth but rich spiritual wealth. Therefore, she has a great charisma and Milkman is fascinated by her though she is not pretty.

Through the creation of Pilate, Morrison aims to call on people to return to the origin of life and keep the nice human nature during the process of socialization. She wants people to reconsider the relationship between human beings and nature, thereby finding the glorious humanity which has been lost in the modern civilization.

\subsubsection{Milkman — A Soul Salved by Nature}

Meanwhile, returning to nature can give human beings a psychical baptism. Nature can soothe and save the soul of 
human beings. Returning to nature can make one forget worldly worries and salve one's conscience. In the materialistic era, people need a kind of purification and nourishing of the soul, a real peace of the mind. Take Milkman as an example. When he takes materialism as his creed, he cannot own the peace of the mind. Then as he is far away from the civilized North, his experience of the woods, hunters and killing makes him close to wild nature. After experiencing a series of difficulties during the hunting process, he is too weak to do anything but sit against a tree. Then he begins to meditate. Through the meditation in the thick forest, his lost human nature starts to be awakened. He examines himself and is aware of his indifference and irresponsibility to people around him in the past. He casts off the constraints of his earlier egocentricity and blames himself for lack of compassion for and understanding of those who are around him.

Throwing himself into the embrace of Mother Nature, he is moved deeply by the liveliness and power of life. While he is lying on the woodland under the moonlight, he becomes part of the nature. He understands the meaning of pantheism. In the African pantheistic and deistic system, natural objects hold sacred meaning for people and Africans cherish a kind of religious reverence for Nature. Then, he has a close tie with the earth, the plants and the animals, just like his African ancestors. He realizes and learns his ancestors' intuitive and sensual ability to converse with animals and with nature. "Down either side of his thighs he felt the sweet gum's surface roots cradling him like the rough but maternal hands of a grandfather. Feeling both tense and relaxed, he sank his fingers into the grass. He tried to listen, with his fingertips, to hear what, if anything, the earth had to say..." (p. 281). Resting in the arms of the nature, he has a new understanding of life. In a warm embrace of nature, he feels cleansed spiritually and wears a new psychic garment. Walking on the earth, he laughs heartily and discovers that he no longer limps! The experience of returning to nature purifies him and gives him an unfamiliar peace and a profound change in perspective.

Nature can purify one's soul, enlighten one's soul, expound the space of one's mind, store the energy of one's life and give one limitless source of power and sense of belonging. Under no circumstances can human beings separate from nature. Human beings should exist in harmony with nature.

\subsection{Recovery of the Ancestral Name}

Although Milkman has embraced his ancestral culture and nature, he is still uncertain about who he is and where he comes from before finding his ancestral name accurately. Milkman's perplexity and aimlessness are mainly resulted from his lost identity. It is essential for Milkman to trace the history of his name, till to the one that is real, the ancestor's name.

Milkman's original intention of the journey is to search for the gold; however, his interest in his relatives surpasses his interest in the gold as his journey progresses. In Denville, he gets some idea of his grandparents' names and their hometown's name from Circe. He gets to know "Jake" and "Sing" for the first time in his life. Then in Shalimar, his grandparents' hometown, he gets more information about his grandmother's family, the Byrd family and visits Susan Byrd, one of his relatives. After the first visit of Susan Byrd, Milkman begins to attach importance to blood relationship and feel a sense of belonging. He senses the familiar atmosphere he sensed at Pilate's home previously. He shows much more interest in his family history. In returning to the general store to fix his car, Milkman watches a group of black children playing and singing the blues song Pilate often sings. The children substitute "Solomon" for "Sugarman". While watching the children play and listening to the familiar tune, he starts to miss Pilate, her home and his family members and reflect upon his previous attitude towards people around him. After listening attentively and repeatedly, he realizes that they are singing about his grandfather Jake. He learns to complete, understand, and sing the song that contains the history of his family.

The Song of Solomon is the key that unlocks the door to his family history and the meaning of his life. When he works out the riddle of his familial roots, he regains his lost identity and comes to know fully who he is and where he belongs. He returns to his true self. Therefore, when he runs into the general store, he finds his eyes shining with great happiness from the shop window glass. The second visit to Susan Byrd confirms his knowledge about his ancestors' names and he feels exhilarated. He rises in fuller recognition of his own identity; and he comes to understand his place in a cultural and family community, thereby becoming spiritually independent and free. He does not fail to meet his grandfather's expectation. He helps him find his real name "Jake Solomon" and takes him home finally. Moreover, he is eager to share it with the black people at home in Michigan. He begins to understand his aunt Pilate and feel much closer to her whom he regards queer and somewhat despises before. During the process of his search for his lost identity, he pursuits truthfulness, goodness, and beauty unwittingly and his heart which was previously empty and at loss is enriched.

After recovering his real name, Milkman begins to pay attention to the meanings of names on the way back to Michigan. "He read the road signs with interest now, wondering what lay beneath the names" (p. 333). He realizes 
the importance of names. Although Milkman fails to find any gold during this trip, he understands fully his place in the world. He is no longer a black man with a white heart but a real African American.

\section{Conclusion}

To sum up, Milkman travels back both in space and time to his ancestors' world, to the days of slavery when his ancestors moved in wagons toward the Promised Land. The long voyage in the land of the ancestors helps him gain the knowledge of his past, and he finds himself gradually immersed in his ancestors' traditional culture. Finally when he is acknowledged as one member of the tribe, purified by the nature and recovers his ancestral names, he owns a sense of belonging. Through the story of Dead family, especially, Milkman's unwitting search for a sense of belonging in Song of Solomon, Morrison explains her proposition that as long as human beings face the past bravely, return to their roots, return to innocence, and recognize their true selves, they will live a happy and meaningful life in a world full of material desires. Song of Solomon conveys Morrison's view to the readers successfully, set them thinking profoundly and provides them with spiritual strength. The view of returning to the ancestral culture, nature and one's true self and learning to tolerate and love others, thereby owning a sense of belonging is a way out for the black people as well as all humankinds in the modern world with a heterogeneous cultural background, which is what Morrison has been exploring consistently and looking for persistently.

\section{References}

Ahmad, Soophia. (2008). Women Who Make a Man: Female Protagonists in Toni Morrison's Song of Solomon. Atenea, 28, 59-73.

Fabre, Genevieve. (1988). Genealogical Archaeology or the Quest for Legacy in Toni Morrison's Song of Solomon. In Nellie Y. McKay (Eds.), Critical Essays on Toni Morrison (pp. 105-113). Boston: G. K. Hall \& co.

Fauset, Arthur Huff. (1996). The negro's cycle of song. In Cary D. Wintz. (Eds.), The Politics and Aesthetics of "New Negro" Literature (pp. 227-229). New York \&London: Garland Publishing, Inc.

Hubbard, Dolan. (1994). The sermon and the African American literary imagination. Columbia: University of Missouri Press.

Lobodziec, Agnieszka. (2010). The South in Toni Morrison's Song of Solomon: Initiation, Healing and Home. Black Theology: An International Journal, 8, 32-52. http://dx.doi.org/10.1558/blth.v8i1.32

Mbalia, Doreatha Drummond. (1991). Toni Morrison's Developing Class Consciousness. London and Toronto: Associated University Presses.

McKay, Nellie Y. (1988). Introduction. In Nellie Y. McKay (Eds.), Critical Essays on Toni Morrison (pp. 1-15). Boston: G .K. Hall \& co.

Middleton, Joyce Irene. (2007). From Orality to Literacy: Oral Memory in Toni Morrison's Song of Solomon. In Valerie Smith (Eds.), New Essays on Song of Solomon (pp. 19-39). Beijing: Peking University Press.

Morrison, Toni. (1994). Conversations with Toni Morrison. Danille Kathleen Taylor-Guthrie (Eds.), Jackson: University Press of Mississippi.

Morrison, Toni. (1977). Song of Solomon. New York: Alfred A. Knopf.

O'Shaughnessy, Kathleen. (1988). "Life life life life": The Community as Chorus in Song of Solomon. In Nellie Y. McKay (Eds.), Critical Essays on Toni Morrison (pp. 125-134). Boston: G .K. Hall \& co.

Rigney, Barbara Hill. (1991). The Voices of Toni Morrison. Columbus: Ohio State University Press.

Samuels, Wilfred D., \& Hudson-Weems, Clenora. (1990). Toni Morrison. Boston: Twayne Publishers.

Smith, Valerie. (2007). Introduction. In Valerie Smith (Eds.), New Essays on Song of Solomon (pp. 1-18). Beijing: Peking University press, 2007.

Zhao Xiao-ming. (2011). Whitening, Revenge and Root-Seeking-Roads for African-American in Song of Solomon. US-China Foreign Language, 9, 589-594. 